\title{
The Lithofacies of Pandua Formation Shale in the Andowia Area, North Konawe, Southeast Sulawesi and Its potential as Petroleum source rock
}

\author{
Mawar Towan Lestari Ramli ${ }^{1}$, Hendra Amijaya ${ }^{1 *}$, and Akmaluddin ${ }^{1}$ \\ ${ }^{1}$ Department Geological Engineering, Faculty of Engineering, Universitas Gadjah Mada, Jalan Grafika 2, Yogyakarta 55281, \\ Indonesia
}

\begin{abstract}
Research on the Late Miocene of Pandua Formation shale in Andowia area, Southeast Sulawesi is fundamental because it is considered to have the potential as a source rock in Manui Basin. This study aimed to determine the lithofacies and its potential as petroleum source rock using megascopic, petrographic, and total organic carbon analyses in Pandua Formation shale. Based on the megascopic and petrographic analysis of outcrops, the shale can be subdivided into 11 lithofacies consists of clayey shale, massive claystone, clastic detritus-rich claystone, massive mudstone, mica-rich mudstone, iron oxide-rich mudstone, low-angle laminated mudstone, massive siltstone, carbon-rich massive siltstone, laminated siltstone, and carbon-rich laminated siltstone. The results of the analysis of 19 samples of shale showed that the total organic carbon (TOC) content was classified as poor to excellent $(<0.5 \%->4 \%)$. The lithofacies with a high concentration of TOC are carbon-rich massive siltstone and carbon-rich laminated siltstone. Both lithofacies were categorized as potentially excellent source rock which the TOC value content is $5.78 \%$ and $5.74 \%$. The result implies the better understanding of the depositional environment and hydrocarbon accumulation potential of the Manui basin for future exploration.
\end{abstract}

\section{Introduction}

Oil and gas are an energy resource that plays a significantrole in supporting the country's economy. Since in the last ten years, crude oil production has decreased [1], further exploration is required to discover new oil and gas fields. One of them is by developing regional investigations in Eastern Indonesia, particularly in the offshore area of Southeast Sulawesi.

The oil and gas potential of the Southeast Sulawesi area, especially in the Manui Basin, is interesting to be further studied. Manui Basin has an active petroleum system and the possibility of hydrocarbon accumulation[2]. This is supported by the discovery of oil and gas seepage near the coast of this area. The discovery of oilseepage in the Lasolo area and gas seepage in the Wawolesea area, North Konawe Regency (Figure 1) proves that this area has an effective source rock. This shows that it can form and expel hydrocarbons (oil and natural gas). The correlation of seismic data and well data shows that the Middle-Late Miocene sequence haspotential as a reservoir and source rock. This is also supported by sample geochemical data from the Abuki- 1 well, which shows a high TOC value at intervals equivalent to the Middle-Late Miocene age of 1.64\%-3.74\% [2].

\footnotetext{
* Corresponding author:hamijaya@ugm.ac.id
}

One of the challenges in oil and gas exploration in this area is the absence of the same outcrops in the onshore area [3]. Thus, there is still a lack of studies related to Miocene units in Southeast Sulawesi, especially regarding the existence of source rock and its potential. The limited understanding of geology, especially regarding the stratigraphy of the Miocene units in Southeast Sulawesi, is very important reason why it is a very important for further studies.

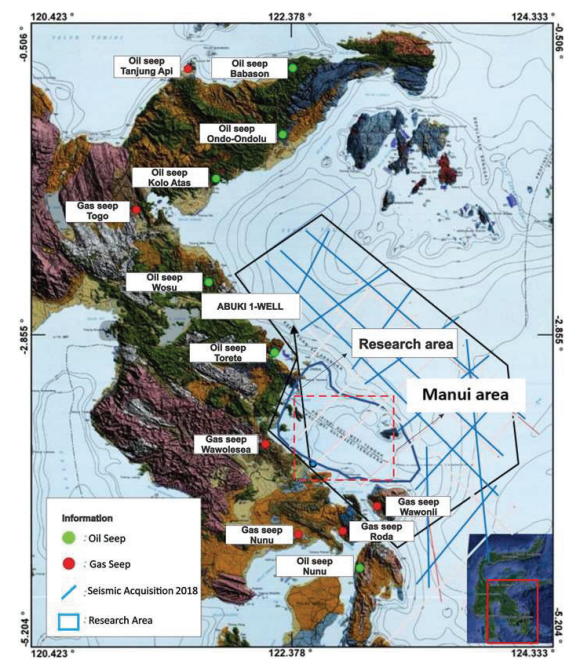

Fig.1. Oil and gas seep in southeast Sulawesi (Badan Geologi, 2019). 
The Pandua Formation is one of the Late Miocene Sulawesi Molasses Formations, which is potential as a source rock [2]. In the Pandua Formation, several shales are found [4][5]. However, studies related to the shale characteristics of this formation are still very limited. Studies concerning the shale characteristics become the basis for determining the potential of rock as a source of hydrocarbons. This paper aims to determine the shale lithofacies and their potential as petroleum source rock. The shale to be discussed is a general term used to denote finegrained sediments such as claystone, mudstone, siltstone, and shale [6].

This study was based on field observation, microscopic analysis, and analysis of total organic carbon in several shale samples of the Pandua Formation. The study area is in the Andowia area, North Konawe Regency, Southeast Sulawesi Province, and the location is shown in Figure 2.

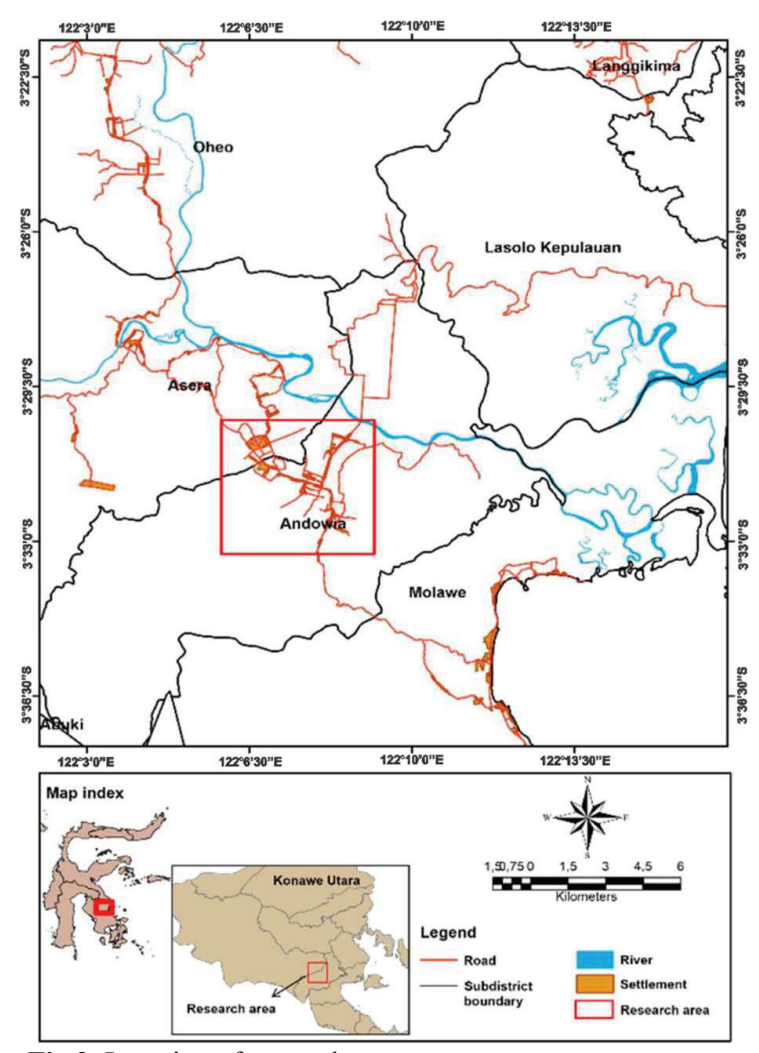

Fig.2. Location of research area.

\section{Methods}

The method used to determine the lithofacies and organic material content of shale in this study was field observation and laboratory analysis. The field analysis was conducted by observing the outcrops of the Pandua Formation. Measured stratigraphic sections were made to determine shale lithofacies based on geometric, lithological, and sedimentary structure parameters. The measured stratigraphic sections have a thickness of $671 \mathrm{~m}$. The limited outcrops found in the field caused manyblank zones of stratigraphic record (Figure 3). The sample from outcrop was taken for laboratory analysis, which are microscopic and total organic carbon (TOC) content analysis.

Microscopic observation by means of petrographic analysis was conducted to see the types of minerals androck microstructure. Analysis of thin section used a Euromax polarization microscope with a magnification of $4 \mathrm{x}$ to $20 \mathrm{x}$ to determine the mineral composition of the shale. Meanwhile, total organic carbon analysis aimed to analyse the content of organic carbon in rock samples. TOC analysis was conducted on 19 selected samples by the combustion method using the Soli TOC cube. For TOC analysis, the sample was crushed into a powder and finer than 100 mesh size. Then the sample was dried inan oven for testing and analysis with a temperature of upto $800^{\circ} \mathrm{C}$.

\section{Results}

\subsection{Lithofacies}

The shale lithofacies (claystone, mudstone, siltstone, and shale) of the Pandua Formation were determined based on megascopic and microscopic analysis of samples. Megascopically, direct field observations were made of the outcrops to identify the texture, structure and geometric of the sediment. Microscopic observation used petrographic analysis to see the types of minerals and rock microstructure. Based on the lithofacies classification by Potter et al. (1980) [6], there are 11 samples of the Pandua Formation lithofacies which are determined based on the clay content of the rock. This classification is combined with variations of the sedimentary structure and mineral composition of the rock.

\subsubsection{Clayey shale}

Clayey shale is rare facies available in the Pandua Formation. Facies emerges in the sandstone as a lens forming a flaser structure and partly as a disconnected lens. The flaser structure formed by these facies has a thickness of up to $2 \mathrm{~cm}$. Some facies are noncontinuouslenses in sandstones with a thickness of up to $8 \mathrm{~cm}$. Petrologically, these facies have dark reddish-grey colour, nearly composed of all claysized material, fissile structure, and very low hardness (Figure 4a). In a thin section, the clay minerals are present with a percentageof $98 \%$. These facies show a very clear fissile structurein thin section analyses (Figure 4b).

\subsubsection{Massive claystone}

Massive claystone is characterized by dark grey to lightgrey colour, clay grain size, a high hardness, and massive structure in the megascopic sample (Figure 4c). The characteristics of these facies forms a massivehorizontal layer with a thickness of up to 6.4 $\mathrm{m}$ and interbedded with varying thickness sandstone. Petrographically, the characteristics of these facies are composed of quartz grains with $100 \mu \mathrm{m}$ grain sizes 
with a percentage of $15 \%$ (Figure $4 \mathrm{~d}$ ). There are seven samples (sample code ANDH6-8, ANDH6-16, ANDH6-19, ANDH6-21, ANDH6-23, ANDH1-9, and ANDH3-3) from these facies has been analysed for its TOC. The analysis results show that the total organic material content ranges from $0.09 \%$ to $0.22 \%$, with the average value of all samples is $0.13 \%$ (Table 1).

\subsubsection{Clastic detritus-rich claystone}

Clastic detritus-rich claystone is characterized by a dark grey colour, a low hardness, and a massive structure in the megascopic sample (Figure 4e). The thickness of these facies is $50 \mathrm{~cm}$. It contains abundant medium- coarse grain size. The characteristics of these facies arecomposed of quartz grains with $220 \mu \mathrm{m}$ with a percentage of $20 \%$. The sediment lithic presents with $80 \mu \mathrm{m}$. The clay matrix is formed with a percentage of $68 \%$. Several other minerals such as chlorite, feldspar, zirconand organic material are present in limited quantities (Figure 4f). A sample (sample code ANDH2-3) from these facies has been analysed for its TOC. The analysis results show that the total organic material content reaches $0.13 \%$ (Table 1 ).

\subsubsection{Massive mudstone}

Massive mudstone is characterized by a greenishgrey colour, silt-clay grain size, a high hardness, and a massive structure in the megascopic sample (Figure 5a). Petrographically, the characteristics of these facies are composed of quartz grains with $220 \mu \mathrm{m}$ of grain sizes with a percentage of $25 \%$. These facies are different from other facies because it contains a considerable amount of tabular muscovite minerals about $15 \%$ with an abundance of sedimentary clastic detritus (lithic).

\subsubsection{Mica-rich mudstone}

Mica-rich mudstone is characterized by a light grey colour, silt-clay grain size, a medium hardness, and a massive structure in the megascopic sample (Figure $5 \mathrm{c})$. Muscovite minerals with interference colour present with tabular to bladed shape, $100 \mu \mathrm{m}$ grain sizesand a percentage of $15 \%$. The clay matrix has a percentage of $40 \%$. Several other minerals, such as feldspar and opaque minerals are present in limited quantities (Figure 5d). TOC analysis was not performed on these facies. However, it is interpreted based on the appearance of colour as having a very low organic material content.

\subsubsection{Iron oxide-rich mudstone}

Iron oxide-rich mudstone is characterized by a reddish-grey colour, silt-clay grain size, a medium hardness, massive structure, and closed fabric in outcrops samples. The red colour of these is estimated to contain high content of iron oxide (Figure 5e). The thickness ofthis facies is $1,2 \mathrm{~m}$. In thin section, this facies contains abundant medium-coarse grain size. The characteristics of these facies are composed of rounded quartz grains (up to $420 \mu \mathrm{m}$ ) with a percentage of $35 \%$. The clay matrix has a percentage of $45 \%$. Several other minerals, such as chlorite, feldspar, and zircon, are present in limited quantities (Figure 5f). A sample (sample code ANDH1-12) has been analysed for its TOC. The analysis results show that the total organic material content reaches $0.17 \%$.

\subsubsection{Low-angle laminated mudstone}

Low-angle laminated mudstone is characterized by brownish-grey colour with a low-angle laminated structure (Figure $5 \mathrm{~g}$ ). The characteristics of these faciesare composed of quartz grains (up to $420 \mu \mathrm{m}$ ) with a percentage of $40 \%$. The presence of this quartz mineral together with muscovite minerals forms a parallel mineral alignment. Muscovite minerals with tabular shape (up to $400 \mu \mathrm{m}$ ) are present with percentage of $12 \%$. The dispersion of muscovite minerals is always associated with clay minerals. The clay matrix has a percentage of $36 \%$. Several other minerals, such asfeldspar and lithic, are present in limited quantities (Figure 5h). A sample (sample code ANDH6-2) has been analysed for its TOC. The analysis results show that the total organic material content reaches $0.12 \%$ (Table 1 ).

\subsubsection{Massive siltstone}

Massive siltstone is characterized by purplish grey colour with massive structure in outcrops samples (Figure 6a). The thickness of these facies is up to 82 $\mathrm{cm}$.It is characterized by subrounded coarse-medium quartzgrains (up to $300 \mu \mathrm{m}$ ) with a percentage of $47 \%$. The clay matrix is formed with a percentage of $30 \%$. Severalother minerals such as feldspar, lithic, chlorite and zircon grains are present in limited quantities (Figure 6band 6c). A sample (sample codes ANDH2-4) from these facies has been analysed its TOC. TOC analysis shows that the total organic material content reaches $0.14 \%$ (Table 1 ).

\subsubsection{Carbon-rich massive siltstone}

Carbon-rich massive siltstone is characterized by the appearance of a field that forms a massive layer of reddish-grey colour with a thickness of up to $2.8 \mathrm{~m}$ (Figure 6d). The characteristics of these facies have a very fine sand grain size, with a high content of organic material. Organic material is present as carbon fleck in rocks at high concentrations. In addition, organic material is present in several other parts as black crystals, the size of coarse sand grains to very coarse filling the rock cracks to form veins. The crystal granules are defined as the results of silicification that occurs simultaneously with the deposition of organic material. This characteristic is also obtained in several other facies, namely carbon laminated siltstone andlaminated siltstone. 
Based on the petrographic analysis, organic material is present in the form of black streaks and partly in the form of brown crystals. The mineral content of these facies is composed of subangular-subrounded quartz with a grain size of $250 \mu \mathrm{m}$. The quartz is present quiteabundantly, up to $40 \%$, followed by the presence of large amounts of hematite and opaque minerals, up to $10 \%$ and $8 \%$. The matrix is present with a percentage of less than $20 \%$. Several other minerals such as feldspar, chlorite, and zircon are present in a small percentage (Figure 6e and 6f). A sample (sample code ANDH4-14)has been analysed for its TOC. The analysis results show that the total organic material content reaches $5.78 \%$ (Table 1).

\subsubsection{Laminated siltstone}

Laminated siltstone is characterized by a reddish grey to blackish-grey colour with a laminated structure (Figure 7a). The thickness of the laminated sediment is 1-3 $\mathrm{mm}$. The presence of a layer on the rock outcrop has the thickness size of $7 \mathrm{~cm}$ and the thickest is up to $80 \mathrm{~cm}$. Megascopically, these facies contain organic material that emerges as carbon flecks and black crystal grains that fill rock fractures. Carbon flecks are disseminated on each laminated rock boundary with various concentrations.

The results of the thin section analysis show that thelaminated structure can be seen indicated by the presence of quartz, muscovite, feldspar, and clay minerals which form a parallel alignment (Figure 7b). Meanwhile, the clay matrix is formed with a percentage of less than 20\%. Several other minerals such as chlorite, feldspar, muscovite, hematite, lithic, and zircon are present in limited quantities (Figure 7c). There are foursamples (sample code ANDH4-5, ANDH4-7, ANDH4-11 and ANDH4-25) have been analysed for its TOC. The analysis results show that the total organic materialcontent ranges from $0.18 \%$ to $0.45 \%$ (Table 1$)$, with the average value of all samples is $0.34 \%$.

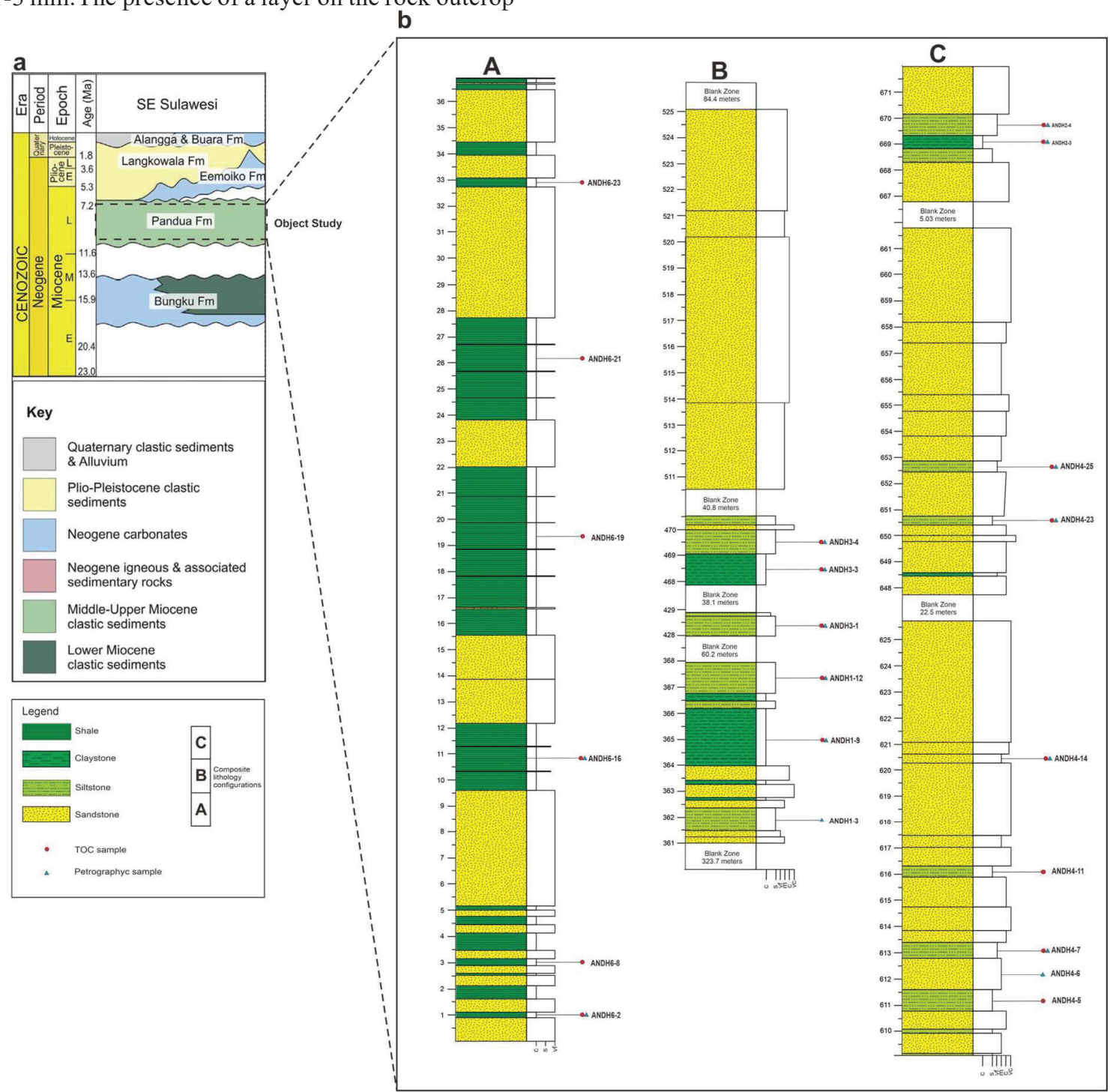

Fig. 3. (a) Stratigraphic column of Neogen sediment in Southeast Sulawesi (modified by Nugraha and Hall, 2018). (b) Stratigraphic measured section column of Pandua Formation in the Andowia area and distribution of the samples. 


\subsubsection{Carbon-rich laminated siltstone}

Carbon-rich laminated siltstone is characterized by a blackish grey to black colour with laminated structure (Figure 7d). The thickness of the laminated sediment is 1-2 mm. Megascopically, these facies contains abundant organic material which spreads evenly in sediment. It is characterized by abundant quartz mineral and organic material with occasional pyrite grains in the outcrop sample. The mineral content of these facies is composed of subangular-subrounded quartz with a grain size up to $500 \mu \mathrm{m}$. The quartz is present abundantly, up to $48 \%$, followed by the clay matrix with a percentage of $22 \%$. The organic material is present abundant in the form of black streaks and partly in brown crystals. Several other minerals such as feldspar, chlorite, and zircon are present in a small percentage (Figure 7e and 7f). A sample (sample code NDH4-23) from these facies has been analysed for its TOC. The analysis results show that the total organic material content reaches $5.74 \%$ (Table 1).

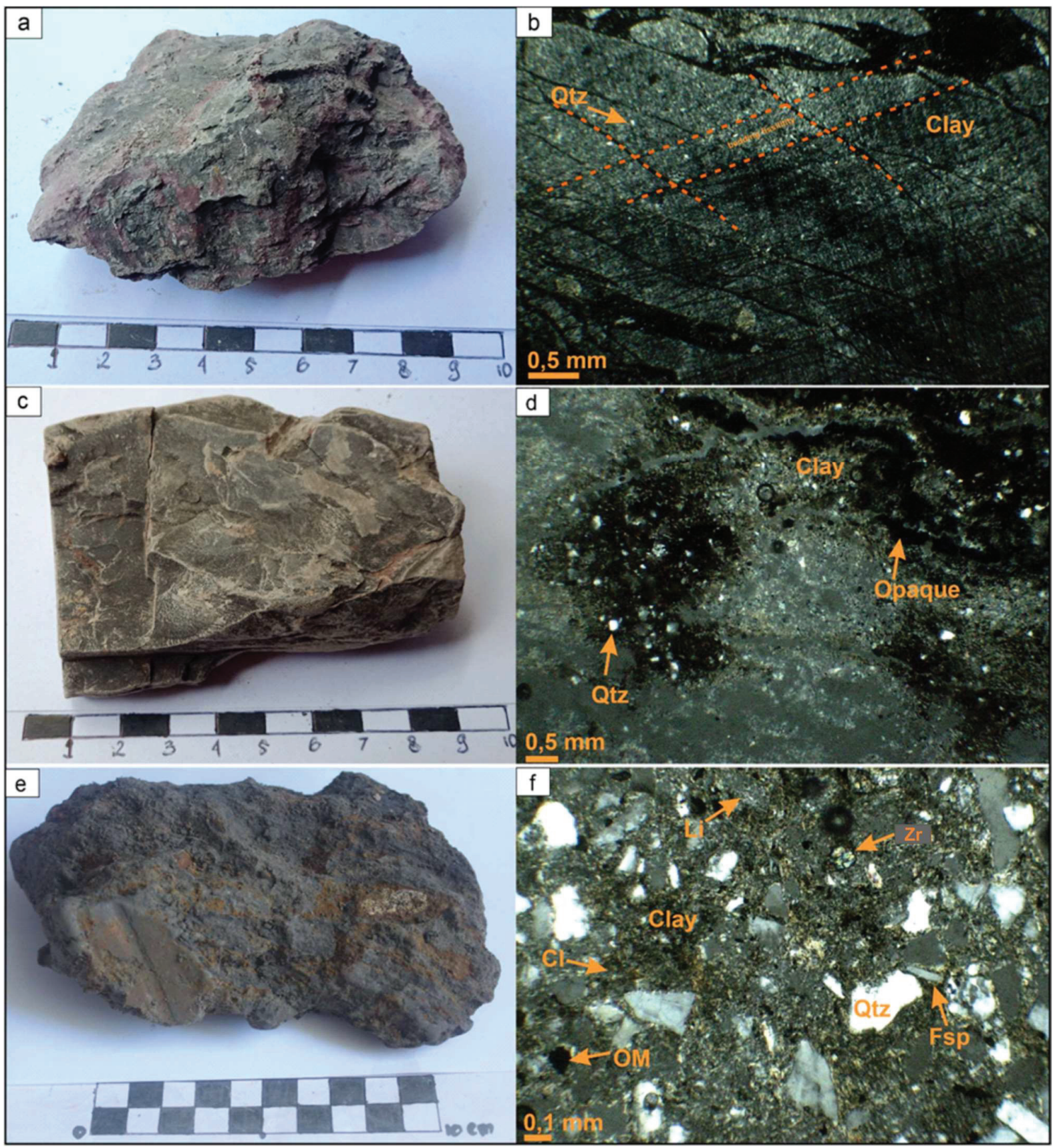

Fig. 4. Macroscopic and microscopic characteristics of some shale lithofacies (a) Macroscopic appearance of the clayey shale. (b) Clayey shale in a thin section shows the fissile structure (c) Macroscopic appearance of the massive claystone. (d) Massive claystone in a thin section. (e) Macroscopic appearance of the clastic detritus-rich claystone. (f) Clastic detritus-rich claystone in a thin section shows the presence of quartz, chlorite, feldspar, lithic and zircon minerals. 


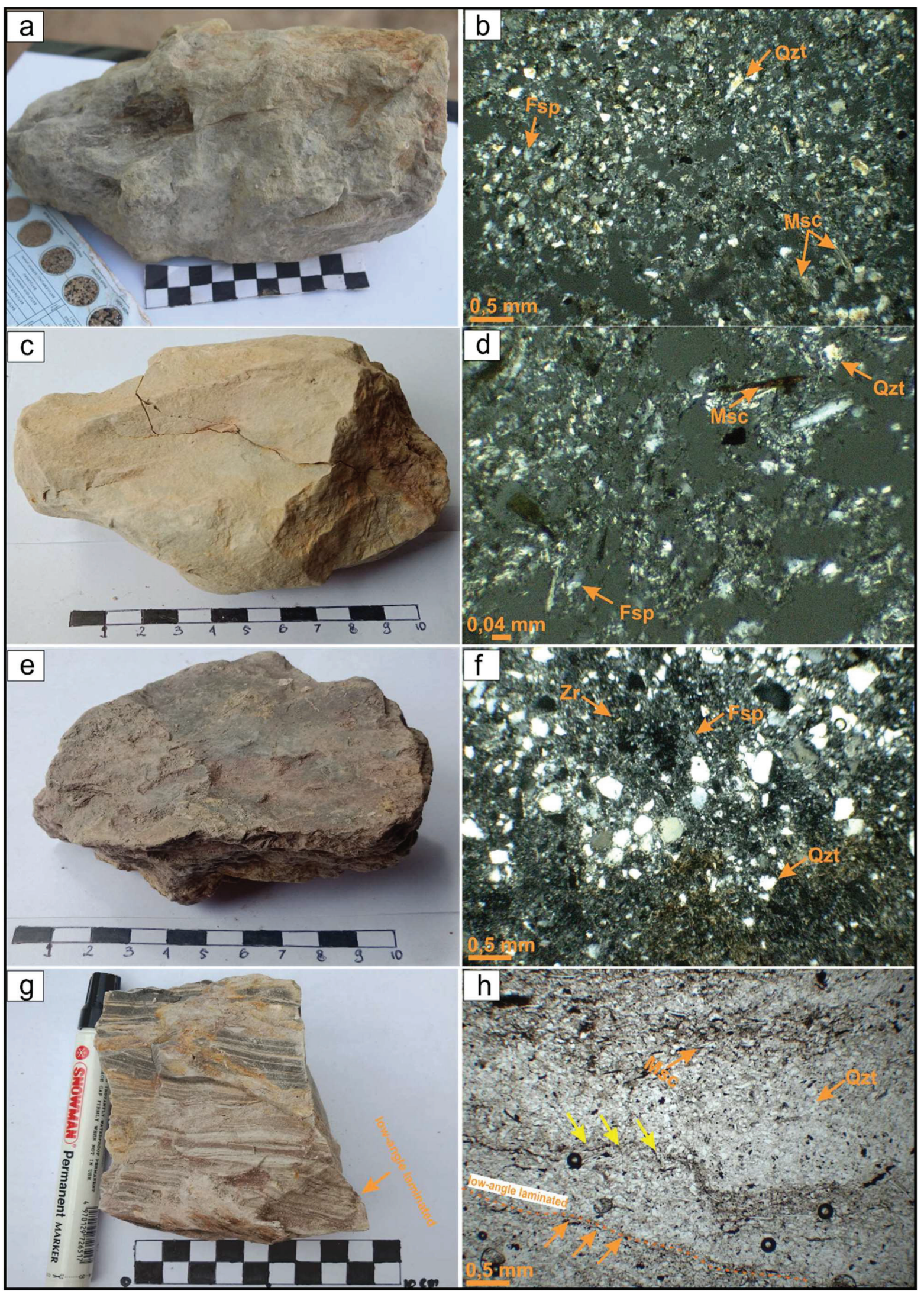

Fig. 5. Macroscopic and microscopic characteristics of some shale lithofacies. (a) Macroscopic appearance of massive mudstone. (b) Massive mudstone in a thin section that shows the presence of quartz, feldspar and muscovite minerals. (c) Macroscopic appearance of mica rich mudstone. (d) Mica rich mudstone in a thin section that shows the presence of quartz, feldspar and muscovite minerals (e) Macroscopic appearance of iron oxide rich mudstone (f) Iron oxide rich mudstone in a thin section shows the presence of rounded quartz, feldspar and zircon minerals. (g) Macroscopic appearance of low-angle laminated mudstone (h) low-angle laminated mudstonea thin section shows the presence of quartz and muscovite minerals with the low angle-lamination structure. 


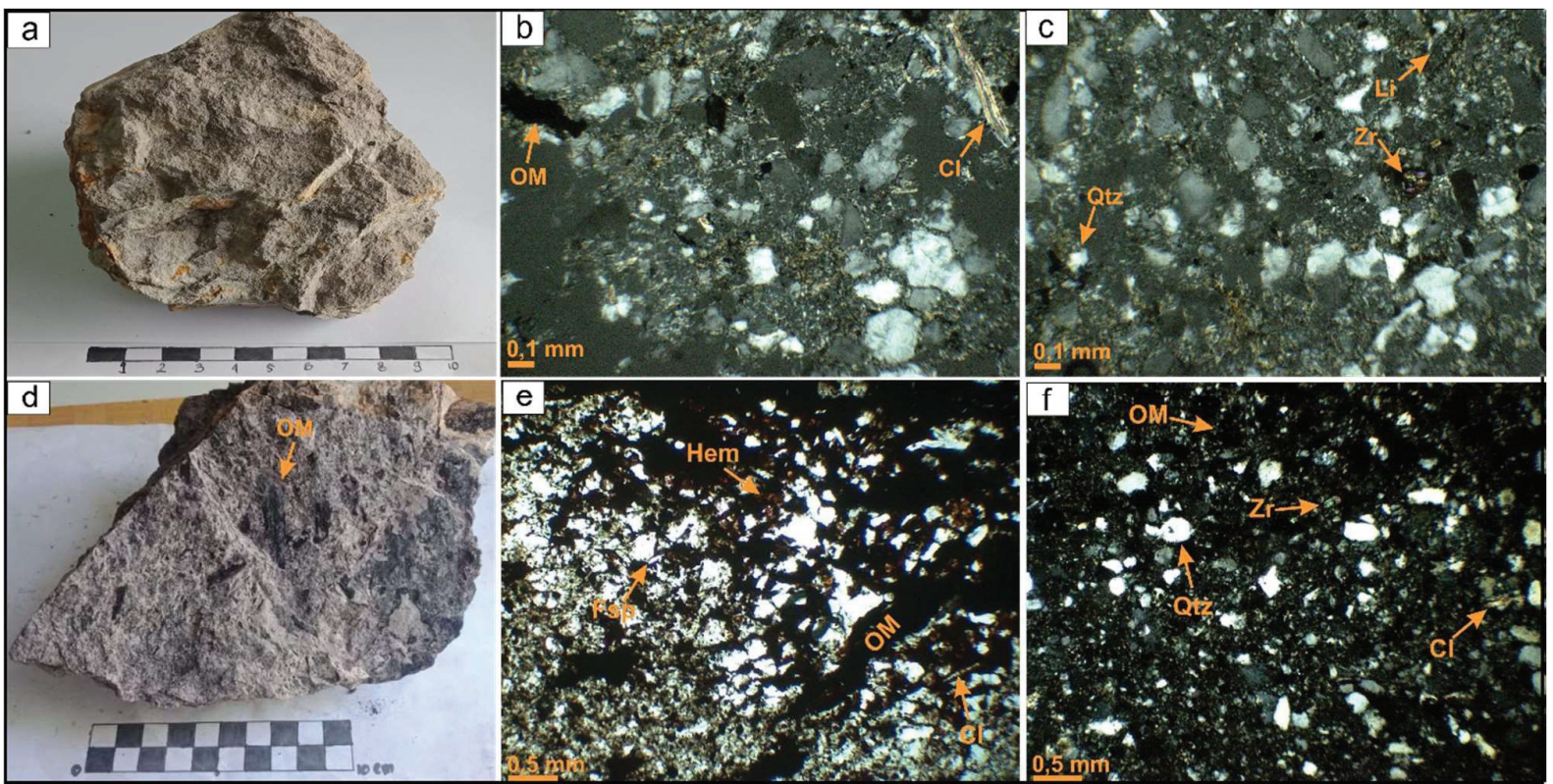

Fig. 6. Macroscopic and microscopic characteristics of some shale lithofacies (a) Macroscopic appearance of the massive siltstone. (b) Massive siltstone in thin section shows the presence of quartz, chlorite and organic materials. (c) Massive siltstone in thin section shows the presence of quartz, lithic, and zircon minerals (d) Macroscopic appearance of the carbon-rich massive siltstone. (e) Carbon-rich massive siltstone in thin section shows the presence of hematite and organic material (f) Carbon-rich massive siltstone in thin section shows the presence of quartz, chlorite, zircon and organic materials.
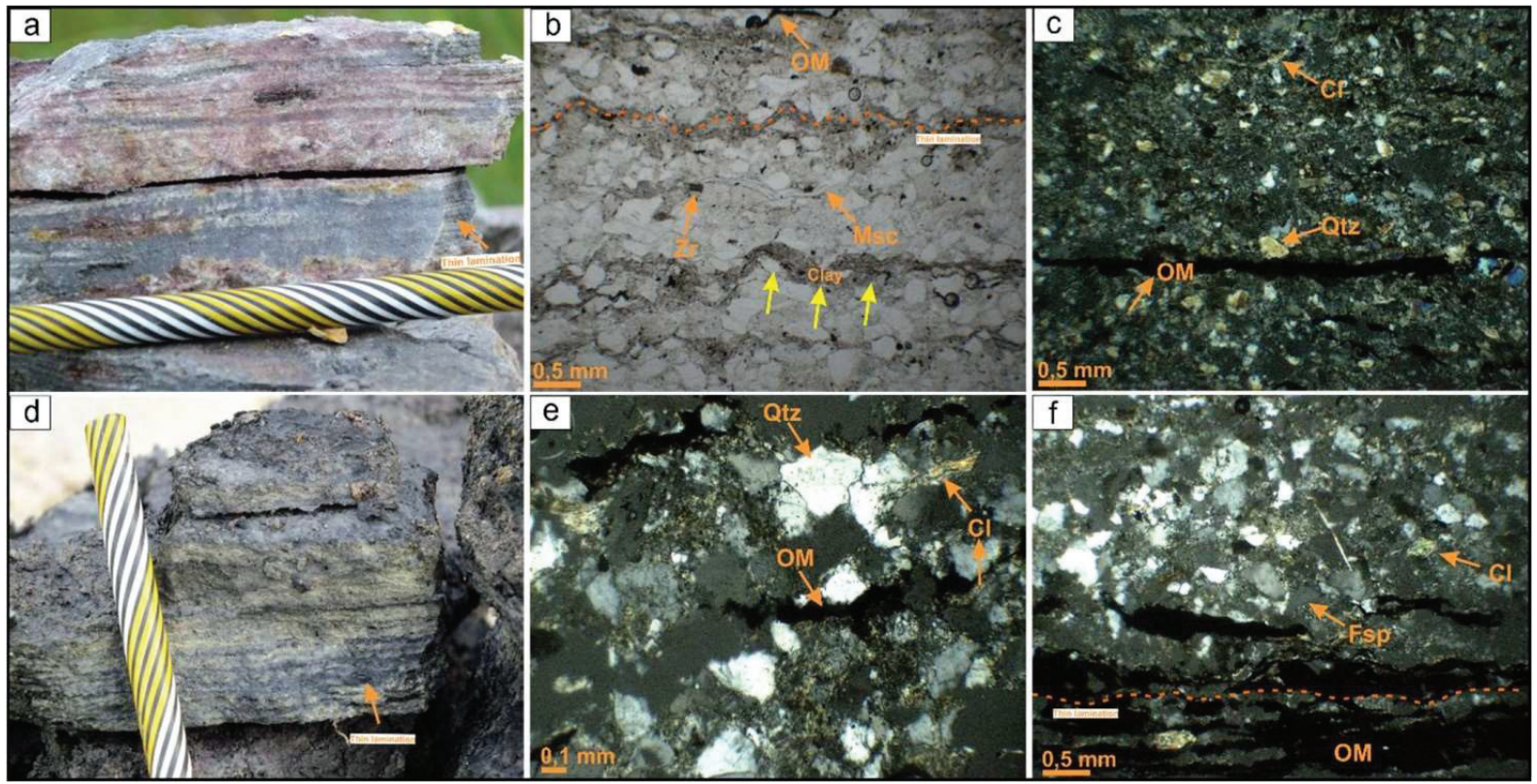

Fig. 7. Macroscopic and microscopic characteristics of some shale lithofacies. (a) Macroscopic appearance of the laminated siltstone facies. (b) Laminated siltstone facies in thin section showing parallel alignments of quartz, clay, and muscovite minerals (c) Laminated siltstone facies in thin section showing the existence of chlorite and organic material formed in parallel (d) Macroscopic appearance of carbon-rich laminated siltstone facies (e) Facies of carbon-rich laminated siltstone in a thin section that shows the existence of mineral organic material at the laminate boundary (f) Facies of carbon-rich laminated siltstone in a thin section that shows the presence of chlorite minerals and alignment of the organic material to form a thin lamination.

\subsection{TOC}

TOC (Total Organic Carbon) analysis of 19 shales samples of the Pandua Formation was conducted. The result of TOC analysis of the shale in this research is range from $0.08 \%$ to $5.78 \%$ (Table 1 ). The facies which contain high value of organic material is carbon-rich massive siltstone facies and carbon-rich laminated siltstone facies. The carbon-rich massive siltstone faciescontain the high content of TOC up to $5.78 \%$ and carbon-rich laminated siltstone facies contain TOC up to $5.74 \%$, followed by laminated siltstone facies with the TOC value range from $0.18 \%$ to $0.45 \%$, followed by massive claystone facies, iron oxide-rich mudstone facies, massive siltstone facies, low-angle laminatedmudstone facies, clastic detritus-rich claystone facies and massive mudstone facies. The TOC value of the other facies is 
Table 1. The distinguished lithofacies with their TOC content of Pandua Formation in Andowia, North Konawe, Southeast Sulawesi

\begin{tabular}{|c|c|c|c|c|}
\hline No & Kode sample & Lithofacies & TOC $(\mathbf{\%})$ & Quality (Peters and Cassa, 1994) \\
\hline 1 & ANDH6-2 & Low angle Laminated Mudstone & 0.12 & Poor \\
\hline 2 & ANDH6-8 & Massive Claystone & 0.09 & Poor \\
\hline 3 & ANDH6-16 & Massive Claystone & 0.22 & Poor \\
\hline 4 & ANDH6-19 & Massive Claystone & 0.16 & Poor \\
\hline 5 & ANDH6-21 & Massive Claystone & 0.13 & Poor \\
\hline 6 & ANDH6-23 & Massive Claystone & 0.15 & Poor \\
\hline 7 & ANDH1-9 & Massive Claystone & 0.09 & Poor \\
\hline 8 & ANDH1-12 & Iron Oxide-rich Mudstone & 0.16 & Poor \\
\hline 9 & ANDH3-1 & Massive Mudstone & 0.08 & Poor \\
\hline 10 & ANDH3-3 & Massive Claystone & 0.21 & Poor \\
\hline 11 & ANDH3-4 & Massive Siltstone & 0.15 & Poor \\
\hline 12 & ANDH4-5 & Laminated Siltstone & 0.18 & Poor \\
\hline 13 & ANDH4-7 & Laminated Siltstone & 0.45 & Excellent \\
\hline 14 & ANDH4-11 & Laminated Siltstone & 0.38 & Excellent \\
\hline 15 & ANDH4-14 & Carbon-rich Massive Siltstone & 5.78 & Poor \\
\hline 16 & ANDH4-23 & Carbon-rich Laminated Siltstone & 5.74 & Poor \\
\hline 17 & ANDH4-25 & Laminated Siltstone & 0.36 & Poor \\
\hline 18 & ANDH2-3 & Clastic Detritus-rich Claystone & 0.13 & \\
\hline 19 & ANDH2-4 & Massive Siltstone & 0.14 & \\
\hline
\end{tabular}

range from $0.08 \%$ to $0.22 \%$. Massive mudstone facies have the lowest TOC value with a percentage of $0.08 \%$ (Table 1). Clayey shale facies are interpretedto have similar TOC as laminated siltstone facies because they have almost the same characteristic.

\section{Discussion}

The lithofacies with high organic material content are the facies carbon-rich massive siltstone and carbonrichlaminated siltstone. In general, these two facies have thecharacteristics of larger grain size (silt-fine sand) with alower content of clay and matrix than the other facies. The other studied stating that the highest organic material commonly exhibits the highest matrix porosity, higher gas in place and lower clay content [7]. Laminated silt-sized which contains detrital grains suchas quartz and feldspar with large particle sized and large densities are interpreted as deposits by gravity flow under the influence of gravitational and hydrodynamic processes [8].

The characteristics of the lithofacies and organic material content are shown by the differences in the sediment structure in Pandua Formation shale. Shales with a microstructure, such as a thin parallel laminated structure $(<3 \mathrm{~mm})$, have a higher organic material content than shales with minimal or lacks structure. These can be seen in laminated siltstone facies and carbon laminated siltstone facies. Several researchers also mentioned that the microstructure in the sediments is produced by the preservation of organic material [8].This indicates that the shale with a microstructure has apositive correlation with the abundance of organic material. This relates to the properties and mechanisms of sediment deposition. Other studies are stating that shale with a welllaminated structure and black-coloured domination without bioturbation formed in an anoxic water column and persistent stratified [7].
The characteristics of lithofacies Pandua Formation shale indicating ability to preserve organic material can be recognized from their mineral associations. Lithofacies with pyrite, hematite, zircon and chlorite minerals are associated with high organic material content. Carbon-rich massive siltstone and carbon-rich laminated siltstone contain pyrite, zircon, chlorite minerals and high organic material as much as $5.74 \%$ and $5.78 \%$.

Meanwhile, several other facies that do not have similar mineral associations only contain small organic material which are from $0.08 \%$ up to $0.22 \%$. This shows that shale with the presence of pyrite, zircon, and chlorite mineral association positively correlates to the abundance of organic material. The presence of thepyrite mineral commonly used as an indicator to indicate the reducing conditions [9]. These show that the high preservation of organic material in this research was deposited in anoxic/ euxinic conditions [9]. The result indicates that environmental conditions of deposition strongly influence the preservation of organic material. The sedimentation and deposition process affect the organic matter abundance and characteristics of shale mineral types [10].

The lithofacies with a high concentration of TOC are carbon-rich massive siltstone and carbon-rich laminated siltstone. Thus, it has an excellent potential as a source rock to produce hydrocarbons. The TOC analysis shows that Pandua Formation shale exposed inthe Andowia area, North Konawe mostly does not have the potential as a source rock. Nevertheless, there are some shale shows the potential as excellent source of hydrocarbons.

\section{Conclusions}

Megascopic and thin section analysis of the Pandua Formation resulted in 11 different lithofacies. The determination of lithofacies was identified based on 
thetexture, structure, and mineral composition. The lithofacies consist of clayey shale, massive claystone, clastic detritus-rich claystone, massive mudstone, mica-rich mudstone, iron oxide-rich mudstone, lowanglelaminated mudstone, massive siltstone, carbonrich massive siltstone, laminated siltstone, and carbon-rich laminated siltstone.

The TOC analysis on 19 samples of the Pandua Formation shows that the potential for shale as a sourcerock can be categorized into two groups. The first groupis categorized as "poor". Therefore, it has less potential to produce hydrocarbons. Meanwhile, the second groupis categorized as "excellent". Thus, it has an excellent to produce hydrocarbons. The results of the TOC analysis show that only some lithofacies of Pandua Formation shale shows the potential as an excellent source rock which are carbon-rich massive siltstone and carbon-rich laminated siltstone. Further studies are needed to identify the distribution of the lithofacies.

The Authors thanks Department of Geological Engineering Universitas Gadjah Mada for the research grant and the laboratory facilities especially the Get in Cicero Laboratory and Sedimentology Laboratory.

\section{References}

1. Dewan Energi Nasional, Outlook Energy Indonesia 2019, Sekretariat Jenderal Dewan Energi Nasional, Jakarta (2019).

2. Badan Geologi, Petroleum prospectivity of Salabangka and the Adjacent area, Preliminary Study, Kementerian Energi dan Sumber Daya Mineral, Bandung (2019).

3. A. Fahruddin, R. Fakhruddin, M. Firdaus, and M. H. Saleh, Indonesia Bulletin of the Geological Society of Malaysia, 70 (2020).

4. A.K. Mubarok, Geologi dan Analisis Provenan Batupasir Daerah Andowia Bagian Barat dan Sekitarnya, Kabupaten Konawe Utara, Sulawesi Tenggara, Skripsi, Institut Teknologi Bandung (unpublished), (2016).

5. M.R. Graha, Geologi dan Provenan Batupasir Daerah Awila Puncak dan Sekitarnya Kabupaten Konawe Utara, Sulawesi Tenggara, Skripsi, Institut Teknologi Bandung(unpublished), (2017).

6. P. Potter, J.Y. Maynard, W. Pryor, Sedimentology of Shale, Springer-Verlag, New Y ork (1980).

7. J. Zaixing, G. Ling, L. Chao, W. Yuan, L. Min, Journal of Paleogeography, 2 (2013).

8. X. Zeng, J. Cai, Z. Dong, L. Bian, Y. Li, Minerals, 8 (2018).

9. G. Xie, S. Liu, G. Xie, W. Hao, Geological Journal, 55 (2019).

10. S. Han, Y. Zhang, J. Huang, Y. Rui, Z. Tang, Minerals, 10 (2020). 